\title{
Multi-temporal photointerpretation analysis of mortality pattern of Ahuehuete (Taxodium mucronatum Ten.) on the coast of the Sabinas River, Coahuila
}

\section{Análisis de fotointerpretación multitemporal del patrón de mortandad de Ahuehuetes (Taxodium mucronatum ten), en el lecho del Río Sabinas, Coahuila}

\author{
SERVÍN-PRIETO, Alan Joel ${ }^{1-3 *}$, MONTEMAYOR-TREJO, José Alfredo ${ }^{1}$, SIFUENTES-MORÍN, \\ Norma Guadalupe $^{1}$ and MIGUEL-VALLES, Enrique ${ }^{2}$ \\ ${ }^{I}$ Instituto Tecnológico de Torreón. Carretera Torreón-San Pedro de las Colonias Km 7.5, Ejido Ana, CP 27170. Torreón, \\ Coah. \\ ${ }^{2}$ Instituto Nacional de Investigaciones forestales, agrícolas y pecuarias CENID-RASPA. Gómez Palacio, Dgo. \\ ${ }^{3}$ InstitutoTecnológico Superior de Lerdo
}

ID $1^{\text {st }}$ Author: Alan Joel, Servín-Prieto / ORC ID: 0000-0002-5534-7875, CVU CONACYT ID: 255753

ID $1^{\text {st }}$ Co-author: José Alfredo, Montemayor-Trejo / ORC ID: 0000-0001-8222-286X, CVU CONACYT ID: 201396

ID $2^{\text {nd }}$ Co-author: Norma Guadalupe, Sifuentes-Morín / ORC ID: 0000-0003-4724-5294, CVU CONACYT ID: 713430

ID $3^{\text {rd }}$ Co-author: Enrique, Miguel-Valles / ORC ID: 0000-0001-9110-1584, CVU CONACYT ID: 638868

DOI: 10.35429/JSL.2021.24.8.14.19

Received March 30 2021; Accepted June 30, 2021

\begin{abstract}
A study was conducted to determine the mortality pattern in the tree species of Ahuehuetes in the Río Sabinas bed of the state of Coahuila in the period from 2000 to 2018 , using the photointerpretation as an analysis tool of satellite images from the LANDSAT $5 \mathrm{TM}$ sensor, and aerials images obtained using an unmanned aerial vehicle (UAV). The NDVI values were obtained from the reflectance values for three sections of the Sabinas's River bed, which were the object of study in the present investigation, with the results obtained when performing the Chi-square test, it was possible to quantify the number of living or dead trees in each study area and taking the time factor as the dependent variable $\left(x^{2}=144.51 ; d f=3 ; p<2.2 * \mathrm{e}^{-16}\right)$. The photointerpretation yielded a total of 517 individuals of the species present at the sampled sites within the established period. 155 specimens were identified for the section of las Adjuntas, of these, three were registered as dead in 2010 and 23 individuals were added for 2018. Later, 111 individuals were registered in the Sabinas section, of which, two were registered as dead in 2010 and 26 more were added for 2018.
\end{abstract}

Photointerpretation, VANT, Ahuehuetes.

\begin{abstract}
Resumen
Se realizó un estudio para determinar el patrón de mortandad en la especie arbórea de Ahuehuetes en el lecho del Río Sabinas en el estado de Coahuila en el periodo del 2000 a 2018, utilizando como herramienta de análisis la fotointerpretación de imágenes satelitales del sensor LANDSAT 5 TM, e imágenes aéreas obtenidas mediante un vehículo aéreo no tripulado (VANT). Se obtuvieron los valores de NDVI a partir de los valores de reflectancia para tres tramos del lecho del Río Sabinas, los cuales fueron el objeto de estudio en la presente investigación, con los resultados obtenidos al realizar la prueba de Chi-cuadrada se logró cuantificar el número de árboles vivos o muertos en cada zona de estudio y teniendo como variable dependiente el factor tiempo $\left(x^{2}=144.51 ; d f=3 ; p<2.2 * \mathrm{e}^{-}\right.$ ${ }^{16}$ ). La fotointerpretación arrojó un total de 517 individuos de la especie presentes en los sitios muestreados dentro del periodo establecido. Se identificaron 155 ejemplares para el tramo de las Adjuntas, de estos, tres se registraron como muertos en 2010 y, se sumaron 23 individuos para 2018. Posteriormente, se registraron 111 individuos en el tramo de Sabinas, de ellos, dos fueron registrados como muertos en 2010 y, se añadieron 26 más para 2018.
\end{abstract}

Fotointerpretación, VANT, Ahuehuetes

Citation: SERVÍN-PRIETO, Alan Joel, MONTEMAYOR-TREJO, José Alfredo, SIFUENTES-MORÍN, Norma Guadalupe and MIGUEL-VALLES, Enrique. Multi-temporal photointerpretation analysis of mortality pattern of Ahuehuete (Taxodium mucronatum Ten.) on the coast of the Sabinas River, Coahuila. Journal Simulation and Laboratory. 2021, 8-24: 14-19

*Correspondence to Author (email: alanjservin@gmail.com)

$\dagger$ Researcher contributing as first Author. 


\section{Introduction}

The riverside vegetation is a unique ecosystem due to the fact that they present a high diversity when acting as biological corridors (San José Wéry et al., 2010), they influence the regulation of the hydrological cycle, they are transition ecosystems between aquatic and terrestrial environments They also add scenic beauty and spaces for recreation (Villanueva et al., 2014). The presence of communities of Ahuehuetes or Sabinos (Taxodium mucronatum Ten), in this type of vegetation are an important component, as they play a key role in the ecosystem functions of wetlands and bodies of water, among others, they help in the recharge of the mantles. water tables and improve water quality (Villanueva et al., 2010), in addition to the dendrochronological potential contained in their growth rings (Correa-Díaz, et al., 2014).

At present, the Río Sabinas, belonging to the San Martín basin in the state of Coahuila, Villanueva et al., (2014), reported that there is not a determined number of dead specimens from the community of sabinos on the banks of the river, However, it is pointed out that there is a fragmentation of the ecosystem due to changes in land use for agricultural purposes.

Remote sensing or remote sensing is a technique that allows obtaining digital information from objects located on a terrestrial surface, without the need to have direct contact with them (Chuvieco, 1990). The analysis of the vegetation and the detection of changes in its patterns are key for the evaluation of natural resources and their monitoring. For this reason, remote sensing is one of the best tools for detecting and quantitatively evaluating vegetation, for managing natural resources and making decisions (Ramírez-Forero, 2012). The objective of this research was to analyze the historical pattern of mortality in the population of Ahuehuete for three sections of the Sabinas River channel through photointerpretation.

\section{Materials and methods}

The study was carried out using specific data provided by the Dendrochronology Laboratory that belongs to the National Institute of Forestry, Agricultural and Livestock Research (INIFAP) at the National Center for Disciplinary Research on Water, Soil, Plant and Atmosphere Relations (CENID RASPA).
These data correspond to 3 sections of the river bed, section 1 is located on the margins of the vicinity of the community of Sabinas, section 2 in the tributary channel of the R. Álamo basin and a last reference section close to the community of Nueva Rosita.

To carry out the photointerpretation analysis, three fundamental stages were involved; In the first instance, aerial photographs were obtained from the National Institute of Statistics and Geography (INEGI), at a scale of 1: 10000 from the year 1980 of the study sites, as well as current images obtained using the WR RGB sensor of the SONY brand with $16 \mathrm{MP}$ resolution and mounted on an unmanned aerial vehicle (UAV), Classic eBee and cartographic databases of mining exploitation in the study area. Second, two water samples were taken in situ, for each of the sections of interest and in accordance with the provisions of NMX-AA014-1980, one of the samples taken was used for an analysis general of water and another for the determination of heavy metals.

Finally, the zoning of the areas where the identification of the presence of the Sabinos species was achieved was carried out.

\section{Aereal images}

Image mosaics were processed and created for the years 2005, 2010 and 2019 with Google Earth ${ }^{\circledR}$ images in order to identify the change in land use over the years. A 2000 x $2000 \mathrm{~m}$ grid was created for this. for the construction of models (Figure 2). The downloaded images were georeferenced and mosaicked using the Qgis 3.4.4 software.

\section{Flight planning}

Three flight polygons were built taking into account factors such as; width of the river bed, presence of riparian vegetation on the river banks and the mean distance with respect to the communication coverage between the station and the UAV.

\section{Image processing}

The processing of the flights was carried out in the Pix4Dmapper ${ }^{\circledR}$ software, in which the capture, geometric correction, geotagging and construction of the ortho mosaic were carried out.

SERVÍN-PRIETO, Alan Joel, MONTEMAYOR-TREJO, José Alfredo, SIFUENTES-MORÍN, Norma Guadalupe and MIGUEL-VALLES, Enrique. Multi-temporal photointerpretation analysis of mortality pattern of Ahuehuete (Taxodium mucronatum Ten.) on the coast of the Sabinas River, Coahuila. Journal Simulation and Laboratory. 2021 
On the other hand, the satellite images were geometrically corrected considering control points identified from ortho rectified images, subsequently the atmospheric correction was carried out using the Dark Object Subtraction model using the equation:

$$
i_{\lambda_{D O S}}=i_{\lambda r a w}-r m i n_{\lambda}
$$

\section{Where:}

$i_{\lambda D O S}:$ Image corrected using the DOS model. $i_{\text {raw }}$ : Raw image.

$\operatorname{rmin}_{\lambda}$ : Minimum value.

\section{Obtaining the values of the vegetation indices}

To obtain the values of the normalized difference vegetation index (NDVI), it was necessary to use the following expression proposed by (Rouse et al., 1974):

$$
N D V I=\frac{N I R-R}{N I R+R}
$$

Where:

NIR: is the reflectivity measured in the near infrared.

$R$ : is the mean reflectivity in the red region.

\section{Characterization}

Some elements of the aerial photographs considered as fundamental to carry out the photointerpretation were taken into account, these are: size, shape, excess, tone, tone and texture.

The size of an object can be determined by comparing an object relative to another that is known, being able to differentiate between shrub trees and bushes (González Vázquez \& Marey Pérez, 2004). Through shape, objects can be classified under certain parameters, since the shapes observed in aerial photographs can be related to real objects.

The shadow component complements the shape element, because on some occasions the characteristics of the objects are not easily recognizable in a vertical plane, in addition, these components are used to identify tree species that present characteristic shapes within an area. Boscosa (National Institute of Statistics, 2005).
The characteristics of tone and color were considered due to the fact that in areas devoid of vegetation, light tones are obtained, while, in areas with the presence of vegetation, tones become dark.

The texture in an aerial photograph allows us to identify the different types of vegetation cover captured at the time of taking, adult trees have a coarse texture while in younger trees their texture is finer (Menéndez \& Núñez, 2009).

\section{Determination of factors that alter the environment}

Three factors that influenced the study area were considered; In the first place, the mining developments present within the hydrological influence zone were considered, taking into account the carry-over of pollutants from the source and downstream. The impact on riparian vegetation caused by population growth and change in land use. On the other hand, the fluctuation in the water volume contributed by the basins was considered, as well as the oscillation of the temperature over time.

\section{Climate analysis}

The data obtained on precipitation and temperature were interpolated by means of the Ordinary Kriging method. Said method from the geostatistical perspective begins by taking into account the concept that the mean is constant but unknown, in addition to using the concept of spatial and temporal correlation of regional variables.

\section{Data analysis}

An analysis of variance was carried out considering time as an important factor, since the repetitions in this work were subject to this factor, that is, the value of the vigor of the vegetation (NDVI) is subject to time. As this is a quantitative interval data, it is assumed that it should behave normally.

The ANOVA factor or analysis of variance of repeated measures, was applied in this project considering the time with three levels and a dependent variable. Table 1. 


\begin{tabular}{|c|l|}
\hline Section & \multicolumn{1}{c|}{ Distance } \\
\hline Section 1 & $<1 \mathrm{~km}$. \\
\hline Section2 & $1: 3 \mathrm{~km}$. \\
\hline Section3 & $>3 \mathrm{~km}$. \\
\hline
\end{tabular}

Table 1 Definition of strata according to the distance from a mine to the main riverbed

Source: Own Elaboration

\section{Results}

The photointerpretation yielded a total of 517 individuals of the species present at the sampled sites within the established period. 155 specimens were identified for the Adjuntas section, of these, three were registered as dead in 2010 and 23 individuals were added for 2018. Later, 111 individuals were registered in the Sabinas section, of which two were registered as dead. in 2010 and, 26 more were added for 2018. Finally, in the witness section of Santa María, 251 specimens were observed with zero records of deaths for the 4 dates observed. Table 2 .

\begin{tabular}{|l|r|r|r|r|r|r|r|}
\hline \multicolumn{1}{|c|}{ Site } & $\mathbf{V}_{\mathbf{2 0 1 8}}$ & $\mathbf{V}_{\mathbf{2 0 1 0}}$ & $\mathbf{V}_{\mathbf{2 0 0 3}}$ & $\mathbf{V}_{\mathbf{1 9 9 0}}$ & $\mathbf{M}_{\mathbf{2 0 1 8}}$ & $\mathbf{M}_{\mathbf{2 0 1 0}}$ \\
\hline Attached & 129 & 152 & 155 & 155 & 23 & 3 \\
\hline Sabinas & 83 & 109 & 111 & 111 & 26 & 2 \\
\hline Santa Maria & 251 & 251 & 251 & 251 & 0 & 0 \\
\hline Total & 463 & 512 & 517 & 517 & 49 & 5 \\
\hline
\end{tabular}

Table 2 Condition of Taxodium mucronatum Ten individuals by site over time

Source: Own Elaboration

On the other hand, a contingency Table (Table 3 ) was created with 0 and 1 from the dead and alive labels, respectively, assigned during the photointerpretation to perform the Chisquare statistical test. It was obtained that the number of living or dead trees in each section depends on the year in which the record was obtained. $\left(x^{2}=144.51 ; d f=3 ; p<2.2 * \mathrm{e}^{-16}\right)$.

\begin{tabular}{|l|r|r|r|r|}
\hline & $\mathbf{2 0 1 8}$ & $\mathbf{2 0 1 0}$ & $\mathbf{2 0 0 3}$ & $\mathbf{1 9 9 0}$ \\
\hline 0 & 54 & 5 & 0 & 0 \\
\hline 1 & 463 & 512 & 517 & 517 \\
\hline
\end{tabular}

Table 3 Contingency table. The row that starts at 0 indicates the number of dead Ahuehuetes and with 1 those that are alive

Source: Own Elaboration

The point value of NDVI was obtained for those pixels that were intercepted with the photointerpretation of the Ahuehuetes condition, alive or dead. The dates used for the analysis were selected approximately one year apart to avoid bias due to seasonal variation, the values obtained are reported in Table 4. No usable scenes were found for the year 2007.

\begin{tabular}{|c|c|c|c|}
\hline Satellite & Resolution & Path/Row & Date \\
\hline \multirow{10}{*}{ Landsat $5 \mathrm{TM}$} & \multirow{10}{*}{$30 \mathrm{~m}$} & \multirow{10}{*}{$29 / 41$} & $15 / 10 / 2001$ \\
\hline & & & $15 / 08 / 2002$ \\
\hline & & & $21 / 10 / 2003$ \\
\hline & & & $26 / 12 / 2004$ \\
\hline & & & $10 / 10 / 2005$ \\
\hline & & & $27 / 09 / 2006$ \\
\hline & & & $18 / 10 / 2008$ \\
\hline & & & $05 / 10 / 2009$ \\
\hline & & & $24 / 10 / 2010$ \\
\hline & & & $27 / 10 / 2011$ \\
\hline
\end{tabular}

Table 4 Dates of acquisition of satellite images Source: Own Elaboration

The statistical analysis for this type of data that has time as a variation factor was carried out with an analysis of variance (ANOVA) of repeated measures. It was run in $\mathrm{R}$ Statistics using the fl-ld.fl command, with three levels and a dependent variable. (Table 5).

\begin{tabular}{|l|l|l|l|}
\hline \multicolumn{1}{|c|}{ Transecto } & Time_1 & ... & Time_9 \\
\hline Attached & NDVI_1 & ... & NDVI_9 \\
\hline Sabinas & NDVI_1 & ... & NDVI_9 \\
\hline Santa Maria & NDVI_1 & ... & NDVI_9 \\
\hline
\end{tabular}

Table 5 Data from a one-factor design with repeated measures

Source: Own Elaboration

Based on the results obtained, it can be interpreted that there is a significantly important variation in the value of NDVI per site; the year, in turn, is also a significant factor within the variation of the NDVI and, the Site: Year interaction tells us that IF there is a significant difference between the sites per year (Table 6).

\begin{tabular}{|l|r|r|r|}
\hline & \multicolumn{1}{|c|}{ Statistic } & df & p-value \\
\hline Site & 5.858 & 1.960 & 0.003 \\
\hline Year & 36.047 & 4.159 & $2.89 \mathrm{e}^{-31}$ \\
\hline Site: Year & 9.974 & 6.456 & $1.02 \mathrm{e}^{-11}$ \\
\hline
\end{tabular}

${ }^{1} 95 \%$ confident.

Table 6 Result of ANOVA.test of repeated measures Source: Own Elaboration

Figure 1 shows that from 2006 there was a decrease in the NDVI of all sections, this could be attributed to environmental issues such as low precipitation and an increase in temperature, loss of water quality, changes in the geomorphology of the river could explain the decrease in vigor since it would limit the availability of water. 


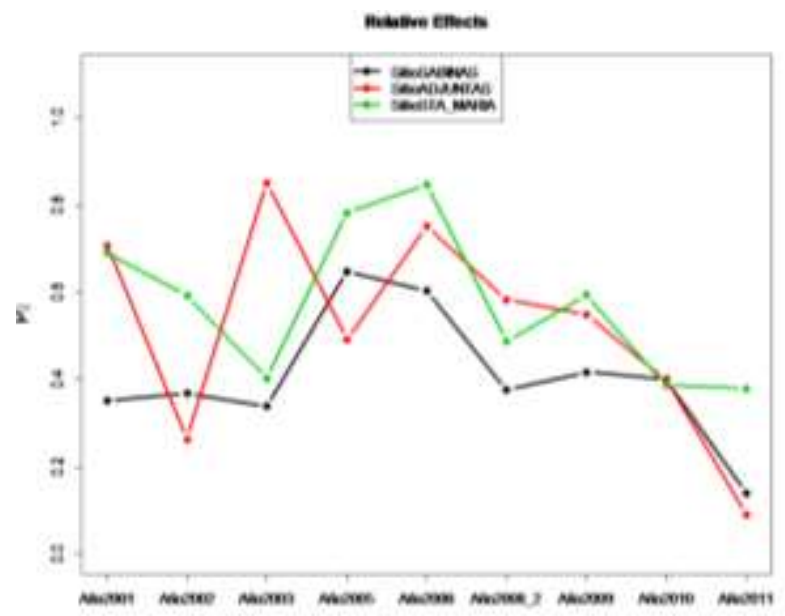

Figure 1 Result of the analysis of variance of repeated measures

Source: Own Elaboration

Figure 2 shows the result obtained in the Sabinas site, where a decrease in the area dedicated to agricultural use is observed, in 1990 the estimated area dedicated to this activity was 182 hectares (Ha) and for 2019 it was $118 \mathrm{Ha} \mathrm{On}$ the other hand, the area used by mines was reduced from $90.8 \mathrm{Ha}$ in 1990 to $56.3 \mathrm{Ha}$ in 2019. In the use of land for the riverbank, the occupation of the river's flood zone was considered, therefore, the surface area of this use increased considerably from $67 \mathrm{Ha}$ in 1990 to $194 \mathrm{Ha}$ in 2019. Regarding urban use, it tended to increase, with a slight drop in its surface, from $1,174.4 \mathrm{Ha}$ in 1990 to $1,193.7 \mathrm{Ha}$ in 2019.

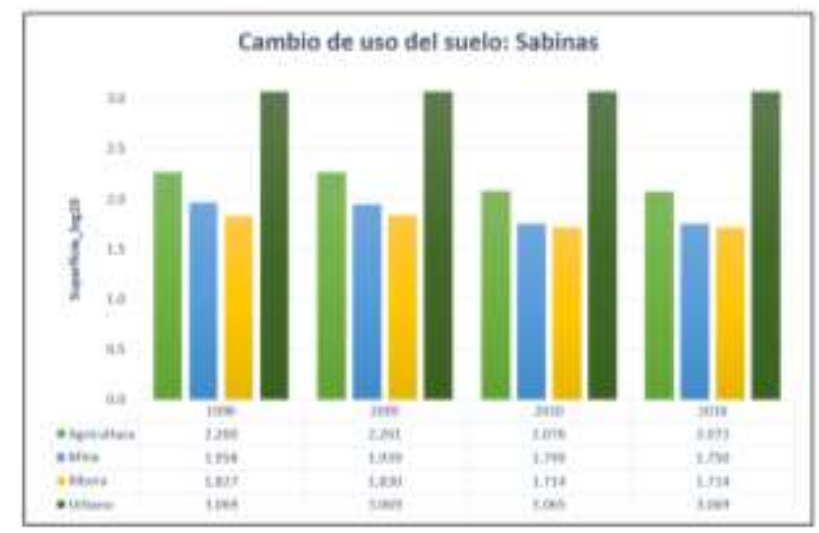

Figure 2 Main uses of altered soil at the Sabinas site. The vertical axis shows the surface with a logarithmic transformation of base 10

Source: Own Elaboration

As highlighted in Figure 3, the results for the Adjuntas site showed an increase in the use of land from mines, which was from $195 \mathrm{Ha}$ in 1990 to $114 \mathrm{Ha}$ in 2019. The opposite case for the use named as no apparent use, which was reduced from $444.8 \mathrm{Ha}$ in 1990 to $381 \mathrm{Ha}$ by 2019. It was also observed that urban use increased almost double its surface, from $69 \mathrm{Ha}$ in 1990 to 115 Ha in 2019.

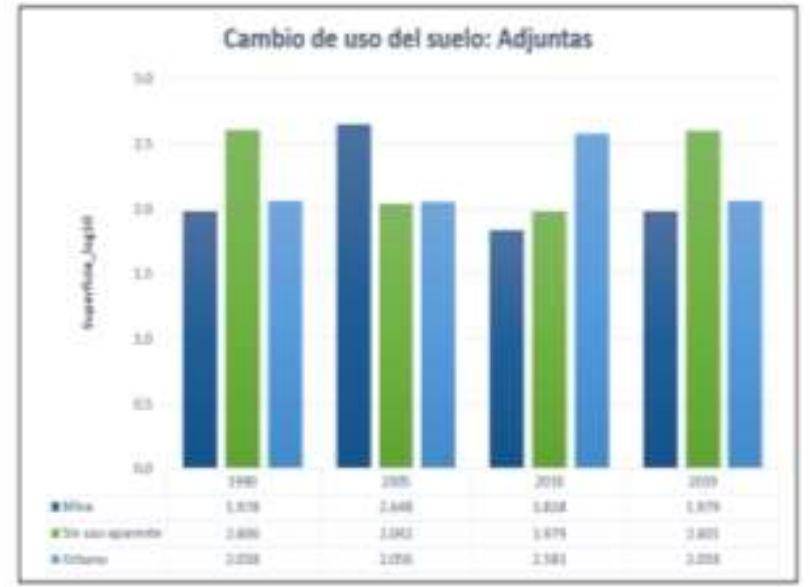

Figure 3 Main uses of altered soil at the Adjuntas site. The vertical axis shows the surface with a logarithmic transformation of base 10

Source: Own Elaboration

On the other hand, Figure 4 illustrates the changes observed in the Santa María site, which indicate that the agricultural use shows a low change, going from $605 \mathrm{Ha}$ in 1990 to $554 \mathrm{Ha}$ in 2019. Land use for the mines showed an initial increase followed by a gradual increase in their surface, from $0 \mathrm{Ha}$ in 1990 to $46 \mathrm{Ha}$ in 2019. Finally, urban use remained relatively constant from 1990 to 2010 with $46 \mathrm{Ha}$, reaching $50 \mathrm{Ha}$ in 2019 .

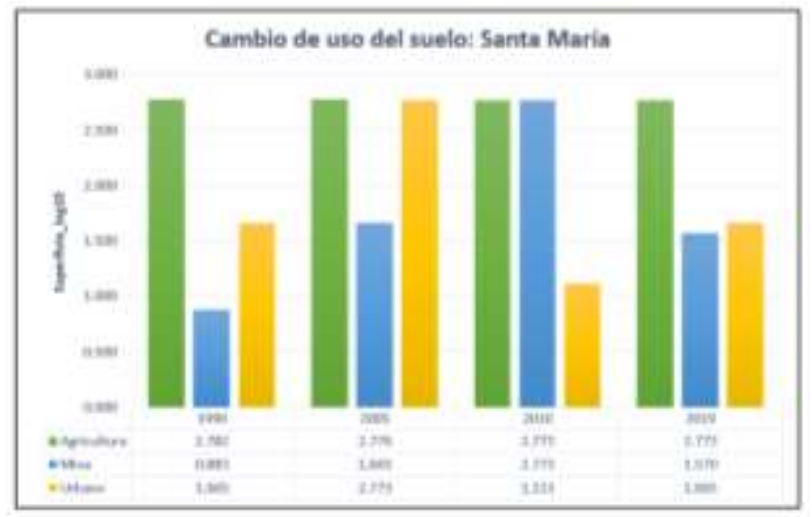

Figure 4 Main uses of disturbed land at the Santa María site. The vertical axis shows the surface with a logarithmic transformation of base 10

Source: Own Elaboration

\section{Conclusions}

The use of a UAV and satellite images to count the Ahuehuete specimens present in the Sabinas River showed a clear idea of the current conditions that this ecosystem maintains. The orthomosaics generated from the UAV were a quick tool to census the population; The information obtained is highly reliable thanks to field validation and the spatial resolution of the orthomosaics ( $3 \mathrm{~cm} /$ pixel), since it relates fundamental aspects of the structure and organization of the population.

SERVÍN-PRIETO, Alan Joel, MONTEMAYOR-TREJO, José Alfredo, SIFUENTES-MORÍN, Norma Guadalupe and MIGUEL-VALLES, Enrique. Multi-temporal photointerpretation analysis of mortality pattern of Ahuehuete (Taxodium mucronatum Ten.) on the coast of the Sabinas River, Coahuila. Journal Simulation and Laboratory. 2021 
It should be noted that the reliability in the classification of land use for the proposed years is based on the visual interpretation, after the algebra of maps with the NDVI and the land use and vegetation map distributed by INEGI, with the support of orthophotos, which which reduces the margin of error of the final map.

The change in land use for mining exploitation is the one that has exerted the greatest pressure on the riparian ecosystem as it is established within the floodplain, interrupting the longitudinal and transversal connectivity of the river necessary for the proper functioning of the ecosystem. Without neglecting the contamination of the water resource and the soil.

On the other hand, various disturbances towards the riverbank by urban growth were observed in the field, among others, the discharge of wastewater directly onto the riverbed; solid waste deposit on the floodplain, as well as the burning of these; A heap of burned garbage was found on the side of an Ahuehuete, which caused the bark and part of the tree trunk to burn.

It is necessary to carry out a more detailed study, taking points in the field of diffuse pollution to understand how the discharge of effluents derived from the mining industries, wastewater and the deposit and burning of solid waste are causing the fragmentation of the riverbank habitat and thus take the necessary measures for its management and restoration.

\section{References}

Chuvieco, E. (1990). Fundamentos de teledetección espacial (1. ed ed.). Colección Monografías y tratados GER. Madrid: Ediciones Rialp.

Chuvieco, E. (2016). Fundamentals of satellite remote sensing: an environmental approach. OCLC: 1012165050.

Correa-Díaz, A., Gómez-Guerrero, A., Villanueva-Díaz, J., Castruita-Esparza, L. U., Martínez-Trinidad, T., \& Cervantes-Martínez, R. (2014). Análisis dendroclimático de Ahuehuete (Taxodium mucronatum Ten.) en el centro de México. Agrociencia, 48, 537-551.

González Vázquez, X. P. \& Marey Pérez, M. F. (2004). Fotointerpretación de los usos del suelo.
Instituto Nacional de Estadística, G. e. I. M. (2005). Guía para la interpretación de Cartografía: fotografía aérea. México: INEGI. OCLC: 651350398.

Menéndez, M. \& Nuñez, V. (2009). El uso de los sensores remotos en los Recursos Naturales. Primera parte: La fotografía aérea y la fotointerpretación. Instituto de Recursos Naturales y Ecodesarrollo, Universidad Nacional de Salta.

Ramirez Forero, S. C. (2012). Analisis de patrones de cambio de cobertura vegetal en el area tropical costera de Tulum. PhD thesis, Centro de Investigación en Geografía y Geomática, México, D.F.

Rouse, J. W., Haas, R. H., Schell, J. A., Deerino, D. W., \& Harlan, J. C. (1974). Monitoring the vernal advancement of retrogradation of natural vegetation.

San José Wéry, A., Manuel Díaz Fernández, P., López-Almansa, J. C., Mongil, J., Mas, P., Ramos MIras, J., Martín García, L. P., \& Luis Rosado, E. (2010). Estudio de las características fisico-químicas de las aguas de los humedales de La Moraña (Ávila). bibtex: inproceedings.

Villanueva, J., Cerano paredes, J., W. Stahle, D., Constante García, V., Vázquez Salem, L., Estrada Ávalos, J., \& Benavides Solorio, J. d. D. (2010). Árboles Longevos en México. Revista mexicana de ciencias forestales, 1, $7-30$.

Villanueva, J., Constante García, V., Cerano Paredes, J., \& Martínez Cifuentes, A. R. (2014). La cuenca San Martín y situación del ahuehuete (taxodium mucronatum ten.) en el río sabinas, Coahuila. INIFAP. ISBN: 978-607-37-0319-2.

Villanueva, J., Instituto Nacional de Investigaciones Forestales, A. y. P. M., \& Centro Nacional de Investigación Disciplinaria en Relación Agua-Suelo-Planta-Atmósfera (2006). Árboles viejos del centro-norte de México: importancia ecológica y paleoclimática. Gómez Palacio, Dgo.: INIFAP, Centro Nacional de Investigación Disciplinaria en Relación AguaSuelo-Planta-Atmósfera. 